\title{
Effect of Metabolic Syndrome on Anxiety in Mice
}

\author{
A. MUKHERJEE AND S. BANERJEE ${ }^{1 *}$
}

Department of Pharmacology, Gupta College of Technological Sciences, Asansol-713 301, ${ }^{1}$ Department of Pharmaceutical Sciences and Technology, Birla Institute of Technology, Mesra, Ranchi-835 215, India

Mukherjee and Banerjee: Metabolic Syndrome Associated Anxiety

\begin{abstract}
Metabolic syndrome is a combination of obesity, dyslipidemia, insulin resistance and hypertension. Clinical evidence indicated the coexistence of metabolic syndrome and depression. However, relatively few studies have been attempted to determine the pathogenesis of metabolic syndrome-associated anxiety. In the present study, the role of metabolic syndrome in the development of anxiety and the role of neurotransmitters in metabolic syndrome-associated anxiety were evaluated in Swiss albino mice. A high-fat and high-carbohydrate diet was used to develop the metabolic syndrome in mice while monitoring elevated fasting blood glucose, hyperlipidaemia and hypertension. Anxiety levels were measured using elevated plus maze and marble burying test with corresponding determination of serum corticosterone levels. The role of $\gamma$-aminobutyric acid and serotonin in metabolic syndrome-associated anxiety were also evaluated. The high-fat and highcarbohydrate fed animals developed metabolic syndrome, characterized by significant high fasting blood glucose and insulin resistance compared to controls. These animals also had significant increase in body weight and waist circumference, low-density lipoprotein and triglyceride levels, reduced high-density lipoprotein content and high blood pressure. Both metabolic syndrome and water avoidance-anxiety groups spent significantly lower time and showed fewer entries into the open arm of elevated plus maze. They also buried more marbles, thus showing clear signs of anxiety when compared to controls. The corticosterone level in metabolic syndrome and anxiety-induced animals were higher than controls. GABA agonists showed a dose-dependent reduction in metabolic syndrome-associated anxiety as revealed by more time spent on the open arm of plus maze with a corresponding decrease in plasma corticosterone levels. Metabolic syndrome animals spontaneously developed anxiety-like behaviour. GABA agonists partially reversed the metabolic syndrome-associated anxiety, suggesting a role for GABAergic pathway.
\end{abstract}

Key words: Anxiety, GABA, metabolic syndrome, obesity, type 2 diabetes

Metabolic syndrome (MS) is a conglomerate of interconnected disorders ${ }^{[1]}$. Almost $25 \%$ of the adults worldwide suffer from MS. It increases the risk of type 2 diabetes, heart attack and stroke in developing nations $^{[2]}$. More than $17 \%$ of the European population in the age group of 44-60 y suffer from MS and $80 \%$ of them has elevated blood pressure ${ }^{[3]}$. MS is one of the commonest lifestyle problems in different parts of Asia that include China and India ${ }^{[4]}$. Among Indians, MS are predominantly common in women due to high carbohydrate intake especially in Asian Indian phenotype ${ }^{[5,6]}$. Late complications of MS coexist with various pathological complications like neuropathy, colorectal cancer, menstrual disturbances and arthritis thus broadening the co-morbidities ${ }^{[7]}$. Antioxidantrich diet especially food containing cinnamon and hydroxycinnamic acids has been shown to prevent MS-associated cardiovascular complications ${ }^{[8]}$. MS has also been associated with CNS disorders like anxiety and depression ${ }^{[9]}$. Anxiety disorders have been independently associated in MS population ${ }^{[10]}$. On the other hand, higher evening cortisol levels are common in patients suffering from a major depressive disorder. Bardet-Biedl syndrome (BBS), a condition similar to $\mathrm{MS}$, is associated with obesity, hyperlipidaemia, liver dysfunction as well as elevated insulin and leptin ${ }^{[11]}$. BBS individuals have been shown to be more prone to anxiety disorders. Obesity, induced by carbohydrate diet followed by induction of stress may promote the development of anxiety-like behaviour compared to

This is an open access article distributed under the terms of the Creative Commons Attribution-NonCommercial-ShareAlike 3.0 License, which allows others to remix, tweak, and build upon the work non-commercially, as long as the author is credited and the new creations are licensed under the identical terms

Accepted 19 March 2018

Revised 05 August 2017

Received 20 February 2017

Indian J Pharm Sci 2018;80(3):453-459 
animals on normal diet ${ }^{[12]}$. A transgenic animal model of obesity and diabetes, the $\mathrm{db} / \mathrm{db}$ mice made by a point mutation of leptin receptor gene also showed anxietylike behaviour ${ }^{[13]}$.

Though there is significant clinical evidence of the coexistence of depression, MS and established common therapeutic objective to treat anxiety and depression associated with MS, there are relatively few animal studies trying to determine the pathways linking MS and anxiety. Obesity or type 2 diabetes has been shown to have a bidirectional link with depressive disorder ${ }^{[14]}$. However, whether metabolic disorders may produce anxiety or depression and the effect of antidepressant therapy on the later conditions is less well-characterized.

Many transgenic and drug or diet-induced MS models have been established and are in practice, but a correlation model of anxiety and the metabolic association is less established. In this study, we evaluated the relationship between different behavioural and biochemical aspects of anxiety in association with diet-induced MS on Swiss albino mice. We also determined the primary neurotransmitters responsible for MS-associated anxiety in these animals

\section{MATERIAL AND METHODS}

Normal pellets, maize starch, lard, casein, vitamins and mineral mixture and sodium chloride were purchased from VRK nutritional solutions, Pune, India. Casein (Charotar Casein Company, Vadodara, India). Fructose (Loba Chemie Pvt. Ltd, Mumbai India), diazepam and gabapentin (Sun Pharma Industries Ltd, Mumbai India) phenobarbitone (Piramal Health Care, Mumbai, India) hydroxyzine (Uni-med India, Mumbai, India) and fluoxetine (Cipla Ltd, Mumbai, India) were procured. Triglyceride (TG), total cholesterol (TC) and high density lipid (HDL) were measured using respective kits (Coral Clinical system, Goa, India).

\section{Experimental animals:}

Male Swiss albino outbred mice (18-22 g) were used for the study. Initially, the animals were housed in colony cages and maintained under standard environmental conditions at $25^{\circ}, 12: 12 \mathrm{~h}$ light:dark cycle, and 50-55\% relative humidity, with free access to food and water ad libitum. The Institutional Animal Ethical Committee approved the protocol (GCTS/IAEC/2013SEPT/08) for the study. Groups (6 animals/group): group-1, control group were fed with standard diet kept in normal condition; group-2, anxiety group induced by water avoidance test; group-3, MS group on highfat diet and supplemented with $20 \%$ fructose solution for $4 \mathrm{w}$ (Table 1).

Ingredients for the high-fat diets were mixed, formed into a dough with water, rolled into pellets, wrapped with plastic wrap, and stored at $-20^{\circ}$ until use to minimize oxidation. These small pellets were given to mice every day. Drinking water was supplemented with $20 \%$ fructose solution as the source of highcarbohydrate in the diet.

\section{Modified water avoidance test:}

Apparatus consisted of a plexiglass tank $(45 \times 25 \times$ $25 \mathrm{~cm})$ with a block $(6 \times 4.5 \times 5 \mathrm{~cm})$ at the centre of the floor. The tank was filled with water at $25^{\circ}$ covering up to $1 \mathrm{~cm}$ of the central block. Mice were placed on the block for $1 \mathrm{~h}$ daily in the daytime for three consecutive days keeping at least $18 \mathrm{~h}$ interval ${ }^{[15]}$. All mice were assessed for measuring anxiety using elevated plus maze (EPM). Food intake/mouse/day, the weight of the mice and waist circumference were calculated and lipid profile, oral glucose tolerance, fasting blood sugar, brain corticosterone, blood pressure were measured. The high-fat and high-carbohydrate (HFHC)-fed mice showing $\geq 30$ g body weight, fasting blood glucose of $140 \mathrm{mg} / \mathrm{dl}$ and systolic blood pressure of $130 \mathrm{~mm} \mathrm{Hg}$ were considered as MS.

In the next set of experiment, mice were fed with highfat diet and $20 \%$ fructose water. After $4 \mathrm{w}$ MS mice were divided into 11 groups of six animals each. One group was kept drug-untreated. Rest of the 10 groups were treated with the following compounds: diazepam $(0.5 \text { and } 1 \mathrm{mg} / \mathrm{kg})^{[16,17]}$; phenobarbitone (20 and $40 \mathrm{mg} /$ $\mathrm{kg})^{[18]}$; gabapentin $(10 \text { and } 30 \mathrm{mg} / \mathrm{kg})^{[19]}$; hydroxyzine $(5 \text { and } 10 \mathrm{mg} / \mathrm{kg})^{[20]}$; fluoxetine $(5 \text { and } 10 \mathrm{mg} / \mathrm{kg})^{[21]}$ successively just before the behavioural and brain corticosterone measurement. Changes in food intake, weight of the animal, waist circumference, systolic blood pressure, fasting blood sugar, oral glucose tolerance, and lipid profile were assessed for animals.

\section{Fasting blood glucose and glucose tolerance test:}

Mice were fasted for $6 \mathrm{~h}$ before oral glucose tolerance test (OGTT). At $0 \mathrm{~h}$ fasting blood glucose was measured by tail prick method using one touch glucose strips. Oral gavage of glucose solution $2 \mathrm{~g} / \mathrm{kg}$ ( $40 \%$ aqueous solution) was given. After glucose administration, glucose levels were measured at 30, 60, 90 and 120 $\min ^{[22]}$. 


\section{Lipid profile:}

After eight weeks, the mice were fasted overnight and anesthetized using ketamine and cardiac puncturecollected blood samples were used to measure TC, HDL and TG in plasma. Low-density lipid (LDL) was calculated using the Eqn., $\mathrm{LDL}=\mathrm{TC}-\mathrm{HDL}-\mathrm{TG} / 5.0$ $(\mathrm{mg} / \mathrm{dl})^{[23]}$.

\section{Measurement of blood pressure:}

Non-invasive blood pressure system (IITC Life Sciences, USA) was used to measure systolic and diastolic blood pressure. Mice were placed in a clear plastic restrainer tube with black nose cone and tail hole pieces at either end. Mice were introduced in the tubes and placed on a platform heated to $35^{\circ}$ and allowed to warm for 5-15 min before the experiment. Mice were habituated to the procedure with $10-30$ preliminary cycles; after that data measurements were recorded for each mouse. Measurements were performed at the same time each day between 9 am to $2 \mathrm{pm}$ in a closed room to avoid noise.

\section{Plasma corticosterone assessment:}

Blood was collected retro-orbitally from all the groups of mice at $5.30 \mathrm{pm}$ in the same room under similar condition. Corticosterone was estimated in plasma samples using UV/Vis spectrophotometer (UV/VisNIR spectrophotometer Agilent) using the procedure of Bartos and Pesez ${ }^{[24]}$.

\section{EPM test:}

EPM is made up of two closed and two open arms connected to a central platform. Mice were placed individually in the centre of the EPM, head facing open arm. The time spent in both the open and closed arms were recorded for $5 \mathrm{~min}$. The numbers of entries into the open and closed arms were also counted during the test. An entry was defined as having all four paws within the arms. Data obtained from the experiment were expressed as mean $\pm \mathrm{SEM}^{[25]}$.

\section{Marble burying test:}

Mice were placed in separate cages containing 20 glass marbles (10 mm diameter) evenly spaced on saw

\section{TABLE 1: INGREDIENTS FOR THE HIGH-FAT DIET}

\begin{tabular}{lc}
\hline Component & g/kg of diet \\
\hline Maize starch & 367 \\
Lard & 316 \\
Cassien & 255 \\
Vitamin and mineral mixture & 61 \\
Sodium chloride & 1 \\
\hline
\end{tabular}

dust. After 30 min exposure to the marbles, mice were removed. The number of marbles buried ( $>50 \%$ under saw dust) was determined.

\section{RESULTS AND DISCUSSION}

HFHC diet significantly increased the body weight and waist circumference $(p<0.001)$ of the animals compared to controls indicating the development of central obesity. Initially, the food intake was normal for all the animals, which increased significantly after four weeks in case of HFHC diet animals. Biochemical parameters associated with MS including fasting blood glucose levels were found to be significantly high $(\mathrm{p}<0.001)$ after two weeks in HFHC diet (Table 2). OGTT for mice was also assessed to confirm the insulin resistance. The area under the curve for elevated blood glucose was much higher for HFHC animals when compared to healthy controls (fig. 1) suggesting glucose tolerance an indication of insulin resistance ${ }^{[26]}$. Elevated systolic blood pressures, a diagnostic characteristic for $\mathrm{MS}^{[27]}$ were measured after $4 \mathrm{w}$ of HFHC diet. Systolic blood pressure in HFHC group mice was significantly higher $(p<0.001)$ compare to control animals. Lipid profile of HFHC mice was measured, which also been reported in $\mathrm{MS}^{[28]}$. HFHC diet led to significant increase in LDL and TG and reduction in HDL levels compared to mice receiving normal pelleted diet (Table 2). Hence, it could be concluded that Swiss albino mice on high fat and $20 \%$ fructose water developed signs of MS including high fasting blood glucose, glucose tolerance, hyperlipidaemia including hypertriglyceridemia and hypertension all suggestive of MS development.

To access anxiety levels in HFHC diet-fed mice, EPM test was used. Water avoidance was used to induce anxiety, thus serving as anxiety controls. Mice undergoing the water avoidance stress spent the lowest time in the open arm, which was comparable with HFHC group mice. Both these groups spent significantly lower $(p<0.001)$ time and showed fewer number of entries $(p<0.001)$ in the open arm as compared to control group (fig. 2). Mice undergoing water avoidance stress and on HFHC diet buried significantly more marbles $(\mathrm{p}<0.001)$ when compared to mice on normal chow (fig. 2). Both the above observations suggest the development of anxiety in HFHC group mice, which developed MS. Plasma corticosterone substantiated the behavioural studies. Plasma corticosterone levels were measured for all three groups of mice. While, water avoidance stress 
mice showed higher plasma corticosterone levels, the corticosterone level in HFHC group mice was comparable with both the groups showing significantly higher plasma $(\mathrm{p}<0.001)$ corticosterone levels when compared to control animals (fig. 2).

Primary neurotransmitters involved in MSassociated anxiety were determined using various pharmacological agents by EPM test and corresponding plasma corticosterone levels. Drugs acting as gamma-aminobutyric acid $\left(\mathrm{GABA}_{A}\right)$ agonists including diazepam, phenobarbitone and gabapentin all showed $(\mathrm{p}<0.001)$ dose-dependent recovery from MS-associated anxiety as evidenced by more time spent on the open arm of the EPM and a corresponding decrease $(p<0.001)$ in plasma corticosterone levels (fig. 3A and B). However, serotonin modulators like fluoxetine and hydroxyzine failed to reverse the MSassociated anxiety and plasma corticosterone levels in HFHC-fed animals. The above results suggested that MS may result in anxiety disorder in mice, which may be $\mathrm{GABA}_{\mathrm{A}}$ receptor mediated.

TABLE 2: EFFECT OF HFHC DIET ON DEVELOPMENT OF MS IN MICE

\begin{tabular}{lcc}
\hline & Control & $\begin{array}{c}\text { High-fat and high- } \\
\text { carbohydrate }\end{array}$ \\
\hline $\begin{array}{l}\text { Fasting blood } \\
\text { glucose }\end{array}$ & $115.5 \pm 2.33 \mathrm{mg} / \mathrm{dl}$ & $264.8 \pm 2.72 \mathrm{mg} / \mathrm{dl}^{* * *}$ \\
LDL & $31.00 \pm 0.58 \mathrm{mg} / \mathrm{dl}$ & $85.33 \pm 4.41 \mathrm{mg} / \mathrm{dl}^{* * *}$ \\
$\mathrm{HDL}$ & $53.67 \pm 1.86 \mathrm{mg} / \mathrm{dl}$ & $42.67 \pm 2.33 \mathrm{mg} / \mathrm{dl}$ \\
Triglyceride & $107.0 \pm 2.65 \mathrm{mg} / \mathrm{dl}$ & $142.3 \pm 3.53 \mathrm{mg} / \mathrm{dl}$ \\
Body weight & $22.0 \pm 1.15 \mathrm{~g}$ & $32.3 \pm 0.88 \mathrm{~g}$ \\
$\begin{array}{l}\text { Waist } \\
\text { circumference }\end{array}$ & $7.47 \pm 0.06 \mathrm{~cm}$ & $8.87 \pm 0.19 \mathrm{~cm}^{* * *}$ \\
$\begin{array}{l}\text { Systolic blood } \\
\text { pressure }\end{array}$ & $113.3 \pm 2.19 \mathrm{~mm} \mathrm{Hg}$ & $132.7 \pm 1.2 \mathrm{~mm} \mathrm{Hg}$ \\
\hline
\end{tabular}

All values are expressed as mean $\pm \mathrm{SEM} ;{ }^{* * *} \mathrm{p}<0.001$

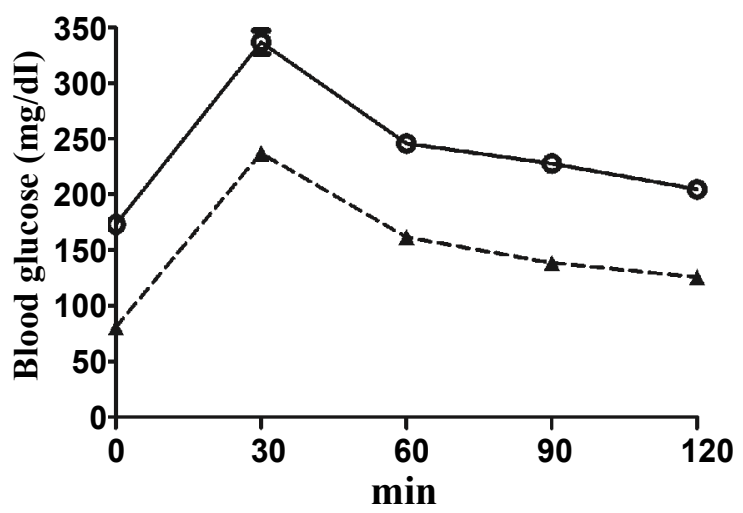

Fig 1: Development of glucose tolerance by HFHC diet $-\Delta-$ Concentration of glucose; $-\circ-$ HFFC, all values are expressed as mean \pm SEM for $n=6$ a

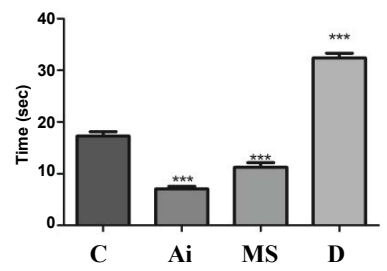

c

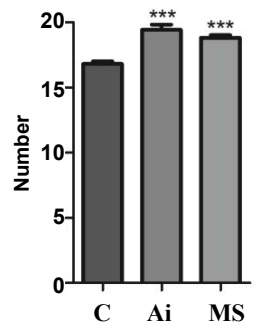

b

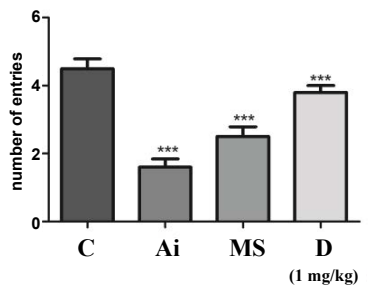

d

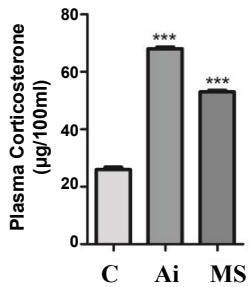

Fig 2: Development of anxiety in MS animals

(a) Time spent in the open arm of elevated plus maze by control (C), metabolic syndrome (MS) and anxiety-induced (Ai) groups and diazepam (D). (b) Number of entries into the open arm of elevated plus maze by control, MS and anxiety-induced groups. (c) Number of marbles buried by control, MS and anxietyinduced groups. (d) Plasma corticosterone levels in control, MS and anxiety-induced groups. All values are expressed as $\operatorname{mean} \pm \operatorname{SEM}$ for $\mathbf{n}=\mathbf{6}, * * * \mathbf{p}<\mathbf{0 . 0 0 1}$

$\mathbf{a}$

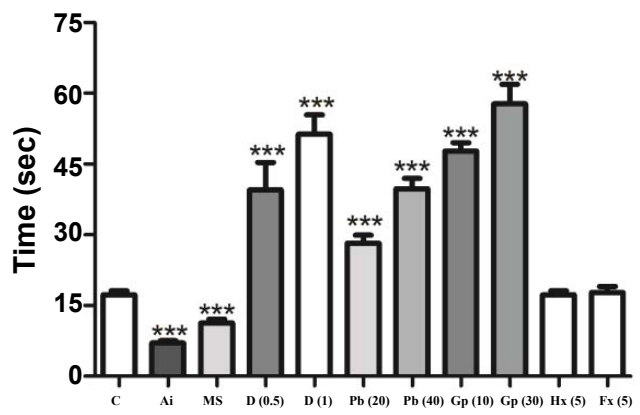

b

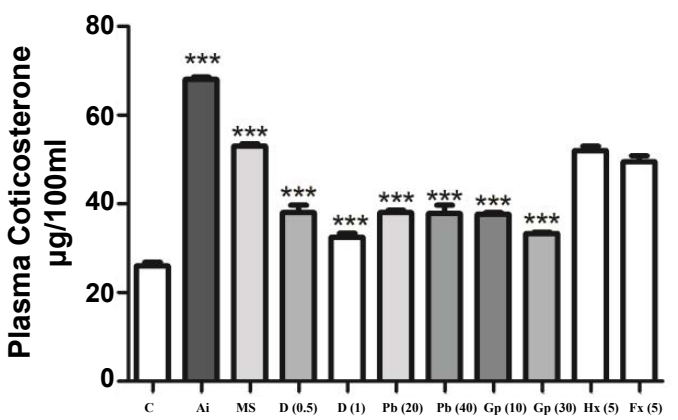

Fig. 3: Effect of antianxiety drugs in MS associated anxiety (a) Effect of control (C) diazepam (0.5 mg/kg: D0.5 and $1 \mathrm{mg} /$ kg: D1), phenobarbitone (20 mg/kg: Pb20 and $40 \mathrm{mg} / \mathrm{kg}: \mathrm{Pb} 40$ ), gabapentin (10 mg/kg: Gb10 and $30 \mathrm{mg} / \mathrm{kg}$ : Gb30), hydroxyzine $(5 \mathrm{mg} / \mathrm{kg}$ : Hx5) and fluoxetine (5 mg/kg: Fx5) on time spent in the open arm of elevated plus maze in MS animals. (b) Effect of diazepam, phenobarbitone, gabapentin, hydroxyzine and fluoxetine on plasma corticosterone levels of MS animals. All values are expressed as mean \pm SEM for $n=6, * * * p<0.001$ 
In the present study, MS was successfully induced using HFHC diet in Swiss albino mice, which was characterized by elevated fasting blood glucose levels, insulin resistance, hyperlipidaemia, and hypertension. Diet-induced model of MS appear to have various advantages over genetic models. The MS in human is a multifactorial disease, which in most cases does not involve mutations in the leptin gene a standard feature in most transgenic animals. Thus the human form of MS is different from the genetic mice models of obesity and $\mathrm{MS}^{[29]}$. The diet-induced models of MS including highfat or high-carbohydrate diet or their combinations were shown to correlate better with the human form of the disease. However, diet-induced murine models of MS mostly involve various strains of rat or $\mathrm{C} 57 \mathrm{bl} / 6 \mathrm{j}$ mice ${ }^{[29]}$. In this investigation high-fat diet was used along with $20 \%$ fructose water for four weeks to induce MS for the first time in Swiss albino mice; the most commonly used outbred laboratory mice. Mice developed distinguishing characteristics of human MS including high fasting blood glucose levels and glucose tolerance, high cholesterol and TG levels, increased central obesity, body weight, and hypertension. Animals on high-carbohydrate diet have been shown to be more prone to anxiety ${ }^{[12]}$, while $\mathrm{db} / \mathrm{db}$ obese mice have shown greater anxiety-like behaviour compared to their $\mathrm{db}+$ counterparts. Anxiety-like behaviour attributes to neuroinflammatory changes with increased levels of cytokines including interleukin-1 $\beta$, tumor necrosis factor- $\alpha$ and interleukin- 6 and a parallel reduction in hippocampal brain-derived neurotrophic factor ${ }^{[30,31]}$. Other studies on Bbs4-null mice, with a mutation that also leads to obesity with elevated insulin and leptin levels similar to MS animals, showed anxiety-related responses and reduced social dominance ${ }^{[32]}$. While a recent study also demonstrated that high-fat dietinduced diabetic mice showed depressive behaviour with impaired 5-HT function ${ }^{[33]}$. In the present study, diet induced-MS-associated increase in anxiety could be demonstrated as measured by less time spent in the open arm of plus maze and number of marbles buried. These behavioural parameters could be correlated with increased plasma corticosterone levels; an established biomarker increased during stress in rodents. Induction of anxiety in neonatal rats might result in upregulation of genes related to serotonin (5-HT) and $\mathrm{GABA}^{[34]}$ in amygdala region. Inescapable foot shock has also been reported to cause hippocampal cell damage along with glutamate/GABA imbalance ${ }^{[35]}$. The GAD65 enzyme is critically involved in regulation of GABA. GAD65 mutants showed hyper excitable brain primarily at the amygdala and hippocampal regions. These animals also showed increased levels of anxiety, while GAD65 deficient animals were found to be less prone to external stress $^{[36]}$. Restraint stress has also shown reduced $\mathrm{GABA}_{\mathrm{A}}$ currents in the amygdala resulting in excessive amygdalar excitability ${ }^{[37]}$. This stress model might also decrease levels of the cortical and hippocampal $\mathrm{GABA}_{\mathrm{A}}$ receptor, thus modulating the functions of HPA axis ${ }^{[38]}$. Studies on human post traumatic stress disorder (combat post traumatic stress disorder patients) using magnetic resonance have shown abnormalities in cortical or parito-occipital-temporal cortical $\mathrm{GABA}^{[39-41]}$. In separation anxiety models (maternal separation; MS) role of GABA has also been documented. MS might enhance tonic GABA currents promoting subsequent neurogenesis and differentiation of GABA neurons during adulthood ${ }^{[42]}$. MS during breastfeeding affects the expression and function of one of the GABA ${ }_{A}$ subunits in a gender specific manner ${ }^{[43]}$. This study demonstrated that diazepam, phenobarbitone and gabapentin, which were all involved in activation of $\mathrm{GABA}_{\mathrm{A}}$ receptors could dose-dependently reverse anxiety-like behaviour in MS induced mice. The above observations suggested the role of GABA pathway in MS-associated anxiety in these animals. However, the brain GABA levels remained unaltered in MS animals when compared to control animals. Hydroxyzine and fluoxetine, which act on the serotonergic system were unable to reverse the MS-associated anxiety disorders suggesting less involvement of serotonergic pathways in the above process.

In the current study, a cost-effective MS model was successfully developed using high-fat diet and $20 \%$ fructose water in Swiss albino mice. These mice also exhibited anxiety-like behaviour with elevated plasma corticosterone levels. $\mathrm{GABA}_{\mathrm{A}}$ agonists partially reversed the MS-induced anxiety thus suggesting the predominant role of the GABAergic pathways in the above process.

\section{Acknowledgement:}

Authors express their gratitude to Prof Late Debesh Chandra Majumdar, Chairman, Trinity trust, Dr. Kalyan K. Sen, principal and all the faculty members of Gupta College of Technological Sciences Asansol, for their constant support and encouragement. Authors also thank the Department of Pharmaceutical Sciences and Technology, BIT, Mesra for its support. 


\section{Financial support and sponsorship:}

Nil.

\section{Conflict of interest:}

The authors declare that this paper content has no conflict of interests.

\section{REFERENCES}

1. Grundy SM, Brewer HB, Cleeman, JI, Smith SC, Lenfant C. Definition of MS report of the National Heart, Lung and Blood Institute/American Heart Association Conference on scientific issues related to definition. Circulation 2004;109;433-38.

2. Zimmet P, Alberti KGM, Kaufman F, Tajima N, Silink M, Arslanian $\mathrm{S}$, et al. The metabolic syndrome in children and adolescents-an IDF consensus report. Pediatr Diabetes 2007;8;299-306.

3. Van Vliet-Ostaptchouk JV, Nuotio ML, Slagter SN, Doiron D, Fischer K, Foco L. The prevalence of metabolic syndrome and metabolically healthy obesity in Europe: a collaborative analysis of ten large cohort studies. BMC Endocr Disord 2014;14;1.

4. Grundy SM. Metabolic syndrome pandemic. Arterioscler Thromb Vasc Biol 2008;28;629-36.

5. Ravikiran M, Bhansali A, Ravikumar P, Bhansali S, Dutta $\mathrm{P}$, Thakur JS, et al. Prevalence and risk factors of metabolic syndrome among Asian Indians: a community survey. Diabetes Res Clin Pract 2010;89;181-88.

6. Radhika G, Van Dam RM, Sudha V, Ganesan A, Mohan V. Refined grain consumption and the metabolic syndrome in urban Asian Indians (Chennai Urban Rural Epidemiology Study). Metabolism 2009;58;675-81.

7. Nerkar D, Mukherjee A, Mehta BK, Banerjee S. Metabolic syndrome associated complications. Int J Pharm Pharm Sci 2015;7;22-25.

8. El-Seedi HR, El-Said AM, Khalifa SA, Göransson U, Bohlin $\mathrm{L}$, Borg-Karlson AK, et al. Biosynthesis, natural sources, dietary intake, pharmacokinetic properties, and biological activities of hydroxycinnamic acids. J Agric Food Chem 2012;60(44):10877-95.

9. Skilton MR, Moulin P, Terra JL, Bonnet F. Associations between anxiety, depression and the metabolic syndrome. Biol Psychiatr 2007;62;1251-57.

10. Kahl KG, Schweiger U, Correll C, Müller C, Busch ML, Bauer $\mathrm{M}$, et al. Depression, anxiety disorders and metabolic syndrome in a population at risk for type 2 diabetes mellitus. Brain Behav 2015;5;e00306.

11. Escalier D. Knockout mouse models of sperm flagellum anomalies. Hum Reprod Update 2006;12;449-61.

12. Santos CJ, Ferreira AV, Oliveira AL, Oliveira MC, Gomes JS, Aguiar DC. Carbohydrate-enriched diet predispose to anxiety and depression-like behavior after stress in mice. Nutr Neurosci 2016;29;1-7.

13. Pintana H, Zemdegs J, Manta S, Chattipakorn S, Penicaud L, Fioramonti X, et al. Impact of metformin and fluoxetine on paradigms assessing anxiolytic/antidepressant-like activities in mice fed a standard or a high fat diet. Fundam Clin Pharm 2016;30;74.

14. Bradesi S, Schwetz I, Ennes HS, Lamy CM, Ohning G,
Fanselow M, et al. Repeated exposure to water avoidance stress in rats: a new model for sustained visceral hyperalgesia. Am J Physiol Gastrointest Liver Physiol 2005;289;G42-G53.

15. Vogt MA, Mallien AS, Pfeiffer N, Inta I, Gass P, Inta D. Minocycline does not evoke anxiolytic and antidepressant-like effects in $\mathrm{C} 57 \mathrm{BL} / 6$ mice. Behav Brain Res 2016;301;96-101.

16. Doukkali Z, Taghzouti K, Bouidida EH, Nadjmouddine M, Cherrah Y, Alaoui K. Evaluation of anxiolytic activity of methanolic extract of Urtica urens in a mice model. Behav Brain Funct 2015;11;1.

17. Hosseinzadeh H, Khosravan V. Anticonvulsant effects of aqueous and ethanolic extracts of Crocus sativus L. stigmas in mice. Arc Iran Med 2002;5;44.

18. Fujita M, Kasai E, Omachi S, Sakaguchi G, Shinohara S. A novel method for assessing bladder-related pain reveals the involvement of nerve growth factor in pain associated with cyclophosphamide-induced chronic cystitis in mice. Eur $\mathrm{J}$ Pain 2016;2;79-91

19. Patel S, Kale PP, Addepalli V, Sarkar A, Savai J. Effect of a combination of duloxetine with hydroxyzine on experimental models of anxiety in mice. Indian J Pharmacol 2015;47;173.

20. Wolak M, Siwek A, Szewczyk B, Poleszak E, Bystrowska B, Moniczewski A, et al. Evaluation of the role of NMDA receptor function in antidepressant-like activity. A new study with citalopram and fluoxetine in the forced swim test in mice. Pharmacol Rep 2015;67;490-93.

21. Olivos DR, McGrath LE, Turner CA, Montaubin O, MietlickiBaase EG, Hayes MR. Intraduodenal milk protein concentrate augments the glycemic and food intake suppressive effects of DPP-IV inhibition. Am J Physiol Regul Integr Comp Physiol 2014;306;R157-63.

22. Aguilar EC, Queiroz MDGMN, Oliveira DAD, Oliveira NJFD. Serum lipid profile and hepatic evaluation in mice fed diet containing pequinut or pulp (Caryocar brasiliense Camb). Food Sci Technol (Campinas) 2011;31;879-83.

23. Tremblay AJ, Morrissette H, Gagné JM, Bergeron J, Gagné C, Couture P. Validation of the Friedewald formula for the determination of low-density lipoprotein cholesterol compared with $\beta$-quantification in a large population. Clinical biochem 2004;37;785-90.

24. Bartos J, Pesez M. Colorimetric and fluorimetric determination of steroids. Pure Appl Chem 1979; 51;2157-69.

25. Chatterjee M, Verma R, Lakshmi V, Sengupta S, Verma AK, Mahdi AA. Anxiolytic effects of Plumeria rubra var. acutifolia (Poiret) L. flower extracts in the elevated plus-maze model of anxiety in mice. Asian J Psychiatr 2013;6;113-18.

26. Winzell MS, Ahrén B. The high-fat diet-fed mouse a model for studying mechanisms and treatment of impaired glucose tolerance and type 2 diabetes. Diabetes 2004;53;S215-19.

27. Sun SS, Grave GD, Siervogel RM, Pickoff AA, Arslanian SS, Daniels SR. Systolic blood pressure in childhood predicts hypertension and metabolic syndrome later in life. Pediatrics 2007;119;237-46.

28. Bozkurt B, Aguilar D, Deswal A, Dunbar SB, Francis GS, Horwich $\mathrm{T}$, et al. Contributory risk and management of comorbidities of hypertension, obesity, diabetes mellitus, hyperlipidemia and metabolic syndrome in chronic heart failure: A Scientific Statement from the American Heart Association. Circulation 2016;134;e535-78.

29. Wong SK, Chin KY, Suhaimi FH, Fairus A, Ima-Nirwana S. Animal models of metabolic syndrome: a review. Nutr Metab 2016;13:65 
30. Dinel AL, André C, Aubert A, Ferreira G, Layé S, Castanon N. Cognitive and emotional alterations are related to hippocampal inflammation in a mouse model of metabolic syndrome. PLoS One 2011;6;e24325.

31. Dinel AL, André C, Aubert A, Ferreira G, Layé S, Castanon $\mathrm{N}$. Lipopolysaccharide-induced brain activation of the indoleamine 2,3-dioxygenase and depressive-like behavior are impaired in a mouse model of metabolic syndrome. Psychoneuroendocrinology 2014;40;48-59.

32. Eichers ER, Abd-El-Barr MM, Paylor R, Lewis RA, Bi W, Lin $\mathrm{X}$, et al. Phenotypic characterization of Bbs4 null mice reveals age-dependent penetrance and variable expressivity. Hum Genet 2006;120;211-26.

33. Zemdegs J, Quesseveur G, Jarriault D, Pénicaud L, Fioramonti X, Guiard BP. High-fat diet-induced metabolic disorders impairs 5-HT function and anxiety-like behavior in mice. Br J Pharmacol 2016;173;2095-10.

34. Sarro EC, Sullivan RM, Barr G. Unpredictable neonatal stress enhances adult anxiety and alters amygdala gene expression related to serotonin and GABA. Neuroscience 2014;258;147-61.

35. Gao J, Wang H, Liu Y, Li YY, Chen C, Liu LM, et al. Glutamate and GABA imbalance promotes neuronal apoptosis in hippocampus after stress. Med Sci Monit 2014;20;499-512.

36. Müller I, Obata K, Richter-Levin G, Stork O. GAD65 haplodeficiency conveys resilience in animal models of stressinduced psychopathology. Front Behav Neurosci 2014;8;265.

37. Liu ZP, Song C, Wang M, He Y, Xu XB, Pan HQ, et al. Chronic stress impairs GABAergic control of amygdala through suppressing the tonic GABAA receptor currents. Mol Brain 2014;7:32.

38. Wisłowska-Stanek A, Lehner M, Skórzewska A, Krząścik P, Maciejak P, Szyndler J, et al. Changes in the brain expression of alpha-2 subunits of the GABA-A receptor after chronic restraint stress in low- and high-anxiety rats. Behav Brain Res 2013;253;337-45.

39. Rosso IM, Weiner MR, Crowley DJ, Silveri MM, Rauch $\mathrm{SL}$, Jensen JE. Insula and anterior cingulate GABA levels in posttraumatic stress disorder: preliminary findings using magnetic resonance spectroscopy. Depress Anxiety 2014;31;115-23.

40. Meyerhoff DJ, Mon A, Metzler T, Neylan TC. Cortical gammaaminobutyric acid and glutamate in posttraumatic stress disorder and their relationships to self-reported sleep quality. Sleep 2014;37;893-900.

41. Michels L, Schulte-Vels T, Schick M, O’Gorman RL, Zeffiro T, Hasler G, et al. Prefrontal GABA and glutathione imbalance in posttraumatic stress disorder: preliminary findings. Psychiatry Res 2014;224;288-95.

42. Feng M, Sheng G, Li Z, Wang J, Ren K, Jin X, et al. Postnatal maternal separation enhances tonic GABA current of cortical layer 5 pyramidal neurons in juvenile rats and promotes genesis of GABAergic neurons in neocortical molecular layer and subventricular zone in adult rats. Behav Brain Res 2014;260;74-82.

43. Leon Rodriguez DA, Duenas Z. Maternal separation during breastfeeding induces gender-dependent changes in anxiety and the GABA-A receptor alpha-subunit in adult Wistar Rats. PLoS One 2013;8;e68010. 